\title{
PERUBAHAN TINGKAT NYERI PADA PASIEN PRIMIGRAVIDA INPARTU KALA I DENGAN PENERAPAN SLOW STROKE BACK MASSAGE BERBASIS TEORI KENYAMANAN KOLCABA
}

\author{
Dwi Rahayu \\ Akademi Keperawatan Dharma Husada Kediri \\ Email: alfarezapriyoputra@yahoo.com
}

\begin{abstract}
ABSTRAK
Untuk mengurangi nyeri selama persalinan kala I digunakan manajemen nyeri baik secara farmakologis maupun nonfarmakologis. Dilakukan penelitian untuk membuktikan bahwa Slow Stroke Back Massage dapat mempengaruhi intensitas nyeri pada pasien primigravida inpartu kala I. Penelitian ini merupakan penelitian eksperimental dengan metode yang digunakan adalah rancangan One Group pretest-Posttest Design. Sample terdiri dari 11 responden yang diambil secara purposive sampling yaitu semua pasien primigravida inpartu kala I fase aktif yang masuk kamar bersalin Rumah Sakit Umum Daerah Kabupaten Kediri selama bulan September hingga Oktober 2014. Variabel yang diukur adalah perubahan intensitas nyeri sebelum dan sesudah dilakukan Slow Stroke Back Massage. Dari penelitian didapatkan data bahwa sebagian besar responden $(72,8 \%)$ mengalami nyeri berat dan sebagian kecil $(27,20 \%)$ mengalami nyeri sedang selama kala I fase aktif. Setelah dilakukan Slow Stroke Back Massage didapatkan data bahwa sebagian besar responden $(72,80 \%)$ mengalami nyeri sedang dan sebagian kecil $(27,20 \%)$ tetap mengalami nyeri berat. Kesimpulan yang didapatkan dari penelitian ini adalah menunjukkan adanya perbedaan intensitas nyeri sebelum dan sesudah perlakuan. Dari uji statistik menggunakan uji t-test $(\alpha=0,05)$ didapatkan hasil t hitung $=6,5$ (t table $=2,228$ ) dengan signifikansi 0,000. Dari hasil ini dapat disimpulkan bahwa Slow Stroke Back Massage mempengaruhi intensitas nyeri pada pasien primigravida inpartu kala I fase aktif. Dari hasil temuan diatas, disarankan agar dalam penelitian selanjutnya digunakan sampel yang lebih besar dengan pengukuran intensitas nyeri pada masing-masing fase dalam kala I fase aktif.
\end{abstract}

Kata kunci: Nyeri, Primigravida Inpartu, Slow Stroke Back Massage

\section{PENDAHULUAN}

Persalinan adalah proses keluarnya bayi dari uterus ke dunia luar pada saat kelahiran (Hamilton, 1995). Persalinan dibagi dalam empat tahap yaitu kala I atau kala pembukaan, kala II atau kala pengeluaran, kala III atau kala uri dan kala IV atau kala observasi. Persalinan kala I dimulai dengan adanya kontraksi uterus dan berakhir bila serviks sudah membuka dengan lengkap (Jensen, 1981). Persalinan kala I dibagi menjadi 2 fase yaitu fase laten dan fase aktif. Pada fase aktif kontraksi uterus menjadi lebih teratur, lebih sering, lebih lama dan lebih kuat (Pritchard, 1991).

Rasa nyeri pada persalinan kala I terjadi karena iskemia pada korpus uteri dan proses dilatasi dari serviks (Sarwono, 2002). Sensasi terhadap nyeri ini bersifat individual dan subyektif. Toleransi terhadap nyeri pada tiap orang berbeda, hal ini karena banyak faktor yang mempengaruhi antara lain lingkungan, latar belakang budaya dan individu itu sendiri (Hamnah, 2003). Bagi wanita yang baru pertama kali melahirkan (Primipara) nyeri persalinan merupakan suatu 
perasaan yang sangat tidak menyenangkan dan kesengsaraan yang lebih, karena pada primipara belum ada pengalaman dan bagaimana cara menanggulangi nyeri dengan tepat (Cohen, 1991).

Untuk mengurangi nyeri digunakan manajemen nyeri yaitu secara farmakologis dan nonfarmakologis, dimana tindakan farmakologis masih menimbulkan pertentangan karena pemberian obat selama persalinan dapat menembus sawar plasenta dan berefek pada fetus (Lawrence, 2003). Metode pengontrolan nyeri secara nonfarmakologis sangat penting. Metode ini membantu mengatasi nyeri selama persalinan sebelum diberikan pengobatan, jadi medikasi tidak selalu mengakhiri rasa nyeri dan wanita akan membutuhkan metode nonfarmakologis untuk menanggulangi rasa nyeri sementara. Metode nonfarmakologis tidak membahayakan bagi ibu maupun janin, tidak memperlambat persalinan jika diberikan kontrol nyeri yang adekuat, tidak mempunyai efek alergi maupun efek obat (Pillitteri, 1999).

Teknik nonfarmakologis yang digunakan untuk mengurangi nyeri selama persalinan antara lain dengan distraksi, relaksasi otot, teknik bernafas, imajinasi, stimulasi kulit dan otot (Slow-Stroke Back massage) dan terapi musik (Cohen, 1991). Teknik stimulasi kulit dan otot (Slow-Stroke Back Massage) menjadi satu alternatif dalam pemberian terapi untuk mengurangi nyeri karena mudah dilakukan (tidak memerlukan keahlian khusus) sehingga dapat dilakukan oleh keluarga/suami, tidak memerlukan biaya yang mahal dan tidak terlalu memerlukan peran aktif dari ibu sehingga dapat dilakukan walaupun respon ibu berlebihan terhadap nyeri.

Masase dan sentuhan, merupakan tehnik integrasi sensori yang mempengaruhi aktifitas sistem saraf otonom (Meek, 1993 dalam Potter \& Perry, 1997). Apabila individu mempersepsikan sentuhan sebagai stimulus untuk relaks, kemudian akan muncul respon relaksasi. Relaksasi sangat penting dalam membantu klien untuk meningkatkan kenyamanan dan membebaskan diri dari ketakutan serta stres akibat penyakit yang dialami dan nyeri yang tak berkesudahan (Potter \& Perry, 1997).

Salah satu tehnik memberikan masase adalah tindakan masase punggung dengan usapan yang perlahan (Slow-Stroke Back Massage). Usapan dengan lotion/balsem memberikan sensasi hangat dengan mengakibatkan dilatasi pada pembuluh darah lokal (Kenworthy et al, 2002). Sensasi hangat juga dapat meningkatkan rasa nyaman (Reeves, 1999). Nilai terapeutik yang lain dari masase punggung termasuk mengurangi ketegangan otot dan meningkatkan relaksasi fisik dan psikologis (Kusyati E, 2006).

Peningkatan rasa nyaman merupakan salah satu tujuan dari Comfort Theory yang di kembangkan oleh Kolcaba. Kolcaba menyatakan bahwa perawatan untuk meningkatkan kenyamanan memerlukan sekurangnya tiga tipe intervensi comfort yaitu : Teknis pengukuran kenyamanan, Coaching (mengajarkan) dan comfort food. Pada penelitian ini, intervensi yang digunakan oleh penelti adalah Comfort food, terapi untuk kenyamanan pasien yang meliputi pemijatan. Dalam hal ini peneliti mengaplikasikan SlowStroke Back Massage untuk memberikan stimulasi kutaneus yang diharapkan akan meningkatkan kenyamanan pasien dan menurunkan nyeri persalinan.

\section{BAHAN DAN METODE}

Desain penelitian ini adalah eksperimen dengan rancangan One Group pre-post test design. Teknik pengambilan sampel adalah purposive sampling, sebanyak 11 pasien primigravida inpartu kala I dengan kriteria inklusi : 1) Pasien primigravida inpartu 2) Persalinan normal, 3) Tanpa komplikasi, 4) Masuk kala I, 5) Tidak dalam pengaruh analgesic, 6) Bersedia sebagai subyek penelitian, 7) Ketuban masih intak (+) 
Variabel independen pada penelitian ini adalah Slow Stroke Back Massage dan variabel dependen: Perubahan Tingkat Nyeri. Pengumpulan data menggunakan Skala Numerical Rating Scale untuk pengukuran tingkat nyeri

HASIL

Distribusi Frekuensi Responden Berdasarkan Intensitas Nyeri Sebelum Diberikan Slow stroke back massage

\begin{tabular}{|l|c|c|}
\hline \multicolumn{1}{|c|}{ Intensitas nyeri } & $\mathbf{F}$ & $\mathbf{\%}$ \\
\hline Tidak nyeri (skala 0) & 0 & $0 \%$ \\
\hline $\begin{array}{l}\text { Nyeri ringan (skala 1- } \\
\text { 3) }\end{array}$ & 0 & $0 \%$ \\
\hline $\begin{array}{l}\text { Nyeri sedang (skala 4- } \\
\text { 6) }\end{array}$ & 3 & $27,20 \%$ \\
\hline Nyeri berat (skala 7-9) & 8 & $\mathbf{7 2 , 8 \%}$ \\
\hline $\begin{array}{l}\text { Nyeri sangat berat } \\
\text { (skala 10) }\end{array}$ & 0 & $0 \%$ \\
\hline \multicolumn{1}{|c|}{ TOTAL } & $\mathbf{1 1}$ & $\mathbf{1 0 0 \%}$ \\
\hline
\end{tabular}

Dari tabel 1 diatas dapat diketahui bahwa sebelum dilakukan slow stroke back massage sebagian besar responden yakni 72,80\% mengalami intensitas nyeri yang berat dan $27,20 \%$ responden mengalami nyeri sedang. Dan tak satupun pasien (0\%) yang tidak mengalami nyeri,nyeri ringan maupun nyeri yang sangat berat.

Setelah diberikan teknik slow stroke back massage dilakukan pengukuran dan observasi kembali terhadap masing-masing responden. Berdasarkan pengukuran yang dilakukan dengan menggunakan skala nyeri 0-10 didapatkan hasil sebagai berikut:
Distribusi Frekuensi Responden Berdasarkan Intensitas Nyeri Setelah Dilakukan Slow stroke back massage

\begin{tabular}{|l|c|c|}
\hline & F & \% \\
\hline $\begin{array}{l}\text { Tidak nyeri } \\
\text { (skala 0) }\end{array}$ & 0 & $0 \%$ \\
\hline $\begin{array}{l}\text { Nyeri ringan } \\
\text { (skala 1-3) }\end{array}$ & 0 & $0 \%$ \\
\hline $\begin{array}{l}\text { Nyeri sedang } \\
\text { (skala 4-6) }\end{array}$ & 8 & $\mathbf{7 2 , 8 0 \%}$ \\
\hline $\begin{array}{l}\text { Nyeri berat } \\
\text { (skala 7-9) }\end{array}$ & 3 & $27,20 \%$ \\
\hline $\begin{array}{l}\text { Nyeri sangat } \\
\text { berat (skala 10) }\end{array}$ & 0 & $0 \%$ \\
\hline \multicolumn{1}{|c|}{ TOTAL } & $\mathbf{1 1}$ & $\mathbf{1 0 0 \%}$ \\
\hline
\end{tabular}

Dari tabel 2 diatas dapat diketahui bahwa intensitas nyeri yang dirasakan pasien setelah diberikan slow stroke back massage adalah tidak satupun pasien (0\%) merasakan tidak nyeri, nyeri ringan dan nyeri sangat berat. $72,80 \%$ responden (8 orang) mengalami nyeri sedang dan $27,20 \%$ responden ( 3 orang) mengalami nyeri berat.

Distribusi Frekuensi Perbandingan Nyeri Primigravida Inpartu Kala I Sebelum dan Sesudah Dilakukan Slow stroke back massage

\begin{tabular}{|c|c|c|c|c|l|}
\hline Resp & \multicolumn{2}{|c|}{ Pre treatment } & \multicolumn{2}{|c|}{$\begin{array}{c}\text { Post } \\
\text { treatment }\end{array}$} & \multicolumn{2}{|c|}{ Keterangan } \\
\cline { 2 - 5 } & & $\begin{array}{c}\text { Kategori } \\
\text { nyeri }\end{array}$ & $\begin{array}{c}\text { Kategori } \\
\text { nyeri }\end{array}$ & \\
\hline 1 & 7 & berat & 6 & Sedang & $\begin{array}{l}\text { Menurun 1 } \\
\text { angka }\end{array}$ \\
\hline 2 & 8 & berat & 7 & Berat & $\begin{array}{l}\text { Menurun 1 } \\
\text { angka }\end{array}$ \\
\hline 3 & 6 & sedang & 4 & Sedang & $\begin{array}{l}\text { Menurun 2 } \\
\text { angka }\end{array}$ \\
\hline
\end{tabular}




\begin{tabular}{|c|c|l|l|l|l|}
\hline 4 & 7 & berat & 6 & Sedang & $\begin{array}{l}\text { Menurun 1 } \\
\text { angka }\end{array}$ \\
\hline 5 & 7 & berat & 5 & Sedang & $\begin{array}{l}\text { Menurun 2 } \\
\text { angka }\end{array}$ \\
\hline 6 & 8 & berat & 8 & Berat & Tetap \\
\hline 7 & 7 & berat & 6 & Sedang & $\begin{array}{l}\text { Menurun 1 } \\
\text { angka }\end{array}$ \\
\hline 8 & 8 & berat & 7 & Berat & $\begin{array}{l}\text { Menurun 1 } \\
\text { angka }\end{array}$ \\
\hline 9 & 6 & sedang & 5 & Sedang & $\begin{array}{l}\text { Menurun 1 } \\
\text { angka }\end{array}$ \\
\hline 10 & 7 & berat & 6 & Sedang & $\begin{array}{l}\text { Menurun 1 } \\
\text { angka }\end{array}$ \\
\hline 11 & 6 & sedang & 4 & Sedang & $\begin{array}{l}\text { Menurun 2 } \\
\text { angka }\end{array}$ \\
\hline
\end{tabular}

Dari hasil tabulasi data dapat dilihat distribusi penurunan nyeri, yaitu:

Turun

: 90.90\% (10 orang)

Tetap

: 9,10\% (1 orang)

Meningkat

: $0 \%$

Dari tabel diatas diketahui bahwa sebelum dilakukan slow stroke back massage, responden yang mengalami nyeri berat dengan nilai 8 ada 3 pasien, 2 pasien mengalami penurunan nyeri sebesar 1 angka dan 1 pasien tidak mengalami penurunan nyeri setelah dilakukan slow stroke back massage. Sementara responden yang mengalami nyeri berat dengan nilai 7 sebanyak 5 pasien, 4 pasien mengalami penurunan nyeri sebanyak 1 angka dan 1 pasien mengalami penurunan nyeri sebanyak 2 angka menjadi nyeri sedang setelah diberikan slow stroke back massage. Responden yang mengalami nyeri sedang dengan nilai 6 sebanyak 3 pasien, mengalami penurunan ( 2 angka) sebanyak 2 pasien dan yang mengalami penurunan ( 1 angka) sebanyak 1 pasien setelah dilakukan slow stroke back massage.

Secara umum dapat diketahui bahwa sebelum dilakukan massage tangan dan kaki terdapat 8 orang pasien yang mengalami nyeri berat dan 3 orang pasien mengalami nyeri sedang, dan setelah dilakukan massage tangan dan kaki terdapat 8 orang pasien yang mengalami nyeri sedang dan 3 orang pasien mengalami nyeri berat.

\section{PEMBAHASAN}

Nyeri Primigravida Inpartu Kala I Sebelum Dilakukan Slow Stroke Back Massage

Sebelum pelaksanaan perlakuan dengan slow stroke back massage untuk melihat pengaruhnya terhadap intensitas nyeri dilakukan pengukuran intensitas nyeri terhadap seluruh responden dengan menggunakan skala nyeri 0-10 dan lembar observasi untuk mengetahui respon obyektif responden.

Seperti terlihat pada tabel 1 bahwa sebelum dilakukan slow stroke back massage, sebagian besar (72,80\%) responden merasakan nyeri berat dan sebagian kecil $(27,20 \%)$ responden merasakan nyeri sedang. Nyeri yang dialami responden disebabkan karena seluruh responden berada dalam fase aktif, dimana sebagian besar responden berada pada fase akselerasi dan sedikit pada fase kemajuan maksimal seperti yang terlihat pada diagram 5. 1. 2. 3. disamping itu rasa sakit yang dialami respoden disebabkan karena kontraksi yang semakin teratur (2-3 kali setiap 10 menit) dengan durasi setiap kotraksi antara 30-40 detik. Selain itu rasa sakit juga dikarenakan intensitas kontraksi yang semakin kuat, yang menggambarkan sebagian besar (81.80\%) responden mempunyai intensitas nyeri sedang dan sebagian kecil $(18,20 \%)$ responden mempunyai intensitas nyeri sedang kuat.

Pada fase aktif, kualitas kontraksi semakin adekut, durasinya lebih lama yaitu antara 30-90 detik, frekuensinya lebih sering yaitu 2-5 menit dan intenitas kontraksinya lebih kuat yang mengakibatkan proses 
dilatasi dan penurunan kepala lebih cepat sehingga nyeri yang dirasakan akan semakin meningkat. Menurut Cohen (1991) pada pembukaan 4-7 cm nyeri yang dirasakan cukup tajam. Rasa nyeri yang semakin meningkat menurut Muhimin, dkk (1986) diakibatkan juga karena tekanan janin terhadap buli-buli, uretra dan rektum. Hal ini didukung oleh Pillitteri (1999) dan Wong (1995) bahwa kemajuan persalinan menyebabkan kontraksi uterus semakin kuat, sehingga iskemia meningkat, anoksia meningkat dan intensitas nyeri yang dirasa semakin berat

\section{Nyeri Primigravida Inpartu Kala I Setelah Dilakukan Slow stroke back massage}

Setelah dilakukan slow stroke back massage untuk mempengaruhi intensitas nyeri pada pasien primigravida Inpartu Kala I dilakukan pengukuran terhadap intensitas nyeri terhadap seluruh responden dengan menggunakan skala nyeri 0-10 dan lembar observasi untuk mengetahui tanda obyektif responden.

Dari hasil pengukuran setelah dilakukan Slow Stroke Back Massagedidapatkan hasil seperti pada table 2 dimana sebagian besar $(72,80 \%)$ responden mengalami nyeri sedang dan sebagian kecil $(27,20 \%)$ responden tetap mengalami nyeri berat. Setelah dilakukan slow stroke back massage tak satupun pasien yang tidak merasakan nyeri dan mengalami nyeri ringan.

Keadaan ini menunjukkan bahwa penurunan nilai nyeri untuk masing-masing individu bervariasi. Dari table 2 dapat diketahui bahwa terdapat 1 orang responden yang tetap mengalami nyeri berat pada intensitas yang sama dengan sebelum dilakukan massage. Pada responden yng mengalami nyeri berat dengan nilai 8 ini menurut hasil penelitian dikarenakan adanya dampak psikologi yang ditimbulkan seperti tidak dapat mengikuti perintah lagi dan tidak dapat diatur untuk alih posisi. Responden tidak kooperatif lagi dengan tindakan yang diberikan, ia lebih berfokus pada pada rasa sakit yang dirasakan pada perut bawah sehingga pemberian slow stroke back massage dirasa kurang membantu.

Dari hasil penelitian seperti pada tabel 2 dapat dijelaskan bahwa slow stroke back massage lebih efektif dalam menurunkan intensitas nyeri pada rentang nyeri sedang. Sedangkan untukrentang nyeri berat slow stroke back massage kurang begitu efektif, hal ini dibuktikan bahwa pada responden yang berada pada rentang nyeri berat penurunan nyerinya hanya 1 angka bahkan ada yang tidak mengalami penurunan nyeri, sedangkan untuk responden yang berada pada rentang nyeri sedang penurunan nyerinya cukup banyak yaitu 2 angka meskipun pada nyeri sedang ada yang menurun hanya 1 angka saja.

Menurut Long (1996) hal ini juga karena nyeri merupakan perasaan tidak nyaman yang betul-betul subyektif dan hanya orang yang menderitanya saja yang dapat menjelaskan dan mengevaluasinya. Nyeri dapat timbul oleh berbagai stimuli, tapi reaksi terhadap nyeri tak dapat diukur dengan obyektif. Oleh karena itu meskipun stimulus nyeri disebabkan oleh hal yang sama yaitu kontraksi uterus tetapi reaksi yang ditimbulkan tiap individu berbeda.

Sementara itu sebanyak $27,20 \%$ responden mengalami penurunan nyeri sebesar 2 nilai dan sebanyak 63,70\% responden mengalami penurunan nyeri sebesar 1 nilai. Penurunan nilai sebesar 2 pada responden yang berada pada rentang nyeri 7 (nyeri berat) menjadi nyeri sedang setelah dilakukan massage dan penurunan nilai 2 pada responden yang berada pada rentang nyeri 6 (nyeri sedang) masih tetap berada pada rentang nyeri sedang hanya pada tingkat intensitas yang lebih ringan. Responden yang mengalami penurunan nyeri 
sebesar 1 pada rentang nyeri 8 (nyeri berat) masih tetap mengalami nyeri berat tetapi pada intensitas yang lebih ringan. Responden yang mengalami penurunan nilai sebesar 1 yang berada pada rentang nyeri 7 (nyeri berat) menjadi nyeri sedang setelah massage, sedangkan responden pada rentang nyeri 6 (nyeri sedang) yang mengalami penurunan nilai sebesar 1 angka masih tetap berada pada rentang nyeri sedang hanya pada intensitas yang lebih ringan.

Bagaimana slow stroke back massage dapat menurunkan intensitas nyeri pada kala I proses persalinan dapat dijelaskan dengan teori Opiate Endogenous. Selama kontraksi, impuls nyeri berjalan dari uterus sepanjang serabut $C$ dan serabut $A$ delta untuk ditransmisikan ke sel $T$ pada Substansia Gelatinosa di medula spinalis untuk selanjutnya disampaikan menuju Korteks Serebri dan diterjemahkan sebagai sensasi nyeri. Stimulasi taktil seperti Massage menuju sel $T$ dan sel sekitar yang berada pada Substansia Gelatinosa di medula spinalis, untuk kemudian impuls yang dibawa oleh sel $T$ ini dibawa menuju Periaquaductal Gray. Untuk kemudian sel ini mengeluarkan enkephalin atau serotonin yang dapat mengaktifasi sel lokal untuk mengeluarkan enkephalin. Impuls yang dibawa oleh serat $C$ dan serat $A$ delta menuju sel $T$ dihambat oleh enkephalin pada presinaptik dan postsinaptik. Impuls yang berasal dari sel $T$ juga menuju Midbrain yang dapat mengaktifkan kontrol penghambat yang ada pada jalur desenden.

Enkephalin merupakan zat penghilang rasa nyeri yang secara alami diproduksi oleh tubuh. Enkephalin dalam menghambat transmisi impuls nyeri bertindak sebagai neurotransmitter atau neuromodulator. Enkephalin ini berada pada sinaps saraf yang akan menurunkan sensasi nyeri. Kadar enkephalin berbeda dari satu orang dengan orang lain, hal ini menjelaskan bahwa rasa nyeri berbeda untuk tiap individu.
Individu dengan kadar enkephalin tinggi akan merasakan nyeri lebih ringan. Stimulasi kulit juga dapat meningkatkan produksi enkephalin.

Mekanisme penurunan nyeri ini juga dapat dijelaskan dengan teori gate control, dimana serat $C$ dan serat $A$ delta yang membawa impuls nyeri yang berasal dari uterus menuju gate synaps yang ada pada medula spinalis. Sedangkan serat sentuhan yang membawa impuls sentuhan dari massage juga menuju gate synaps. Impuls yang berasal dari serat sentuhan menstimulasi serat penghambat nyeri yang dapat mengurangi intensitas impuls nyeri yang akan dibawa ke otak, sehingga dapat mengurangi rasa nyeri.

Menurut hasil penelitian, sebagian besar responden merasakan nyeri yang berlokasi pada perut bawah. Dengan serat sentuhan yang berasal dari tangan dan kaki dapat menurunkan nyeri yang dirasakan, hal ini menjelaskan bahwa tidak harus pada tempat yang sama dengan impuls nyeri untuk membangkitkan enkephalin.

\section{Pengaruh Slow stroke back massage Terhadap Intensitas Nyeri pada Pasien Primigravida Inpartu Kala I}

Dari hasil analisa data dengan menggunakan t-test didapatkan output dimana dengan tingkat kepercayaan sebesar 95\% diperoleh hasil $\mathrm{t}$ hit $=6,500, \mathrm{t}$ tabel $=$ 2,228, karena $\mathrm{t}$ hitung $>\mathrm{t}$ tabel maka disimpulkan bahwa ada perbedaan intensitas nyeri sebelum dan sesudah diberikan slow stroke back massage dengan signifikasi sebesar 0,000 (sangat signifikan). Jadi slow stroke back massage berpengaruh terhadap penurunan intensitas nyeri. Sehingga massage ini dapat diterapkan untuk membantu menurunkan intensitas nyeri pada pasien primigravida Inpartu Kala I. 


\section{SIMPULAN \& SARAN}

\section{Simpulan}

1. Dari hasil pengukuran intensitas nyeri dengan menggunakan skala nyeri 0-10 sebelum dilakukan perlakuan dari 11 orang responden, sebagian besar mengalami nyeri berat dan sebagian kecil mengalami nyeri sedang.

2. Hasil pengukuran intensitas nyeri setelah dilakukan perlakuan (slow stroke back massage) dengan menggunakan skala yang sama diperoleh hasil bahwa sebagian besar responden mengalami penurunan intensitas nyeri dan hanya 1 orang responden yang tidak mengalami penurunan intensitas nyeri.

3. Setelah dilakukan uji statistik dengan $t$ test diperoleh hasil bahwa terdapat perbedaan intensitas nyeri sebelum dan sesudah dilakukan slow stroke back massage.

\section{Saran}

1. Secara uji statistik slow stroke back massage dapat menurunkan intensitas nyeri maka perawat dapat memberikan slow stroke back massage sebagai alternatif intervensi pada ibu Inpartu Kala I.

2. Karena pada penelitian ini tidak memenuhi kuota sampel minimal, maka diharapkan ada penelitian yang sama dengan jumlah sampel yang lebih besar.

3. Pada penelitian ini responden yang diambil sebagian besar berada pada fase akselerasi, untuk mengetahui pengaruh slow stroke back massage terhadap intensitas nyeri pada kala I fase aktif perlu untuk dilakukan penelitian dimana responden diberikan perlakuan pada masing-masing fase di dalam kala I fase aktif. Sehingga benar-benar tercermin pengaruh slow stroke back massage terhadap intensitas nyeri pada kala I fase aktif.

4. Slow stroke back massage mudah dilakukan oleh siapapun dan efektif dipandang dari segi ekonomi, maka dapat diajarkan pada keluarga.
5. Slow stroke back massage merupakan metode yang sangat mudah untuk menurunkan intensitas nyeri, maka perlu untuk disosialisasikan.

\section{KEPUSTAKAAN}

Arikunto, Suharsimi. 2002. Prosedur Penelitian: Suatu Pendekatan Praktek. Edisi revisi V. Jakarta: PT. Rineka Cipta.

Cohen, M. Susan. 1991. maternal, Neonatal and Women's Health Nursing. Pennysilvania: Springhouse.

Chudler, Eric. Physiology, Pathophysiology and Endocrinology of Pain. (Watarts. Uwaterloo.ca/'Sreinis/Pain.html, diakses tanggal 19 April 2014).

Chudler, Eric. Sensory Physiology. (members.aol.com/Bio50/LecNotes/I ecnot 29.html, diakses tanggal 19 April 2014).

Danim, Sudarwan. 2003. Riset Keperawatan: Sejarah dan Metodologi. Editor, Monica Ester. Jakarta: EGC.

Hamilton, Persis Mary. 1995. DasarDasar Keperawatan Maternitas. Alih bahasa, Niluh Gede Yasmin Asih. Edisi 6. Jakarta: EGC.

Hamnah, Salamah Ummu. Juni 2003. Melahirkan Secara Alami Tanpa Rasa Sakit. (Klinikpria.com, diakses tanggal 10 Maret 2014)

Jensen, M. Duncan. 1981. Maternity Care: The Nurning And Family. $2^{\text {nd }}$ Edition. Philadelphia: Mosby year Book.

Kolcaba (2011). Comfort Theory Kolcba. http.currentnursing.com. Diakses pada tanggal 26 September 2014. 
Kozier, Barbara. 1997. Fundamental of Nursing. Philadelphia: W. B. Saunders Company.

Kozier, B (2008). Fundamental of Nursing: Concept, Process, and Practice. Ed. 8. Pearson Education, Inc. New Jersey.

Lawrence Leeman [et...al]. 15 September 2003. The Nature and Management of Labor Pain: Part II Pharmacolog.ic Pain Relief. (Pro Quest Medical Library pg. 1115, www.aafp.org/afp, diakses tanggal 11 Mei 2014).

Mattson, Susan and Smith, Judy E. 2000. Core Curriculum for Maternal-Newborn Nursing. $2^{\text {nd }}$ Edition. Philadelphia: W. B. Saunders Company.

Pillitteri, Adele. 1999. Maternal and Child Health Nursing Care of the Childbearing and Childrearing Family. $3^{\text {rd }}$ Edition. Philadelphia: Lipincott.

Prawirohardjo, Sarwono. 2002. Ilmu Kebidanan. Edisi ketiga. Jakarta: Yayasan Bina Pustaka Sarwono Prawirohardjo.

Pritchard, Jack. A. mac Donald. 1991. Obstetri William. Alih bahasa, R. Hariyadi. Surabaya: Airlangga University Press.

Smeltzer, Suzanne C and Bare, Brenda G. 2001. Buku Ajar Keperawatan Medikal-Bedah Brunner \& Suddarth. Edisi 8. Vol. 1. Alih bahasa, Agung Waluyo. Editor, Monica Ester. Jakarta: EGC.

Sugiyono. 2002. Statistika Untuk Penelitian. Bandung: CV. ALFABETA.

Tomey, M \& Alligood (2006). Nursing Theorist and Their Work. $6^{\text {th }}$ Ed. St.Louis: Mosby ELsivier, Inc.

Thomson, Eleanor Dumont. 1995. Maternity and Pediatric Nursing. Philadelphia: W. B. Saunders Company.
Widodo J Pudjirahardjo, dkk. 1992. Metode Penelitian dan Statistik Terapan. Surabaya: Airlangga University Press.

Wong, Donna and Perry, Shannon E. 1998. Maternal Child Nursing Care. Philadelphia: Mosby Year Book. 